\title{
BMJ Open Has the difference in mortality between percutaneous coronary intervention and coronary artery bypass grafting in people with heart disease and diabetes changed over the years? A systematic review and meta-regression
}

\author{
Peter Herbison, ${ }^{1}$ Cheuk-Kit Wong ${ }^{2,3}$
}

To cite: Herbison $P$, Wong $\mathrm{C}-\mathrm{K}$. Has the difference in mortality between percutaneous coronary intervention and coronary artery bypass grafting in people with heart disease and diabetes changed over the years? A systematic review and meta-regression. BMJ Open 2015;5:e010055. doi:10.1136/bmjopen-2015010055

- Prepublication history is available. To view please visit the journal (http://dx.doi.org/ 10.1136/bmjopen-2015010055).

Received 20 September 2015 Revised 29 October 2015 Accepted 23 November 2015

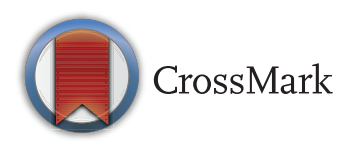

For numbered affiliations see end of article.

Correspondence to Professor Peter Herbison; peter.herbison@otago.ac.nz

\section{ABSTRACT}

Objectives: To examine the difference in outcome between percutaneous coronary intervention $(\mathrm{PCl})$ and coronary artery bypass grafting (CABG), to see if it has changed over the years in diabetics deemed eligible for both treatments; and to contrast the long-term mortality findings with those in non-diabetics.

Design: Meta-analyses using data from randomised controlled trials found by searches on MEDLINE, EMBASE and the Cochrane Controlled Trials Register, from their inception until March 2015.

Setting: Studies had to be randomised controlled trials comparing $\mathrm{PCI}$ with $\mathrm{CABG}$.

Participants: Those taking part in the studies had to have multivessel cardiac or left main artery cardiac disease and be deemed eligible for both treatments.

Interventions: $\mathrm{PCl}$ or $\mathrm{CABG}$.

Primary and secondary outcomes: The primary outcome was all cause mortality. Secondary outcomes were a composite of mortality, stroke and myocardial infarction; cardiovascular death; and MACCE (Major Adverse Cardiac or Cerebrovascular Event). The longest follow-up was used in the analysis.

Results: Among 14 studies (4868 diabetics) reported over three decades, meta-regression shows no relationship between the year of publication and the difference in long term all cause mortality between $\mathrm{PCl}$ and $C A B G$. CABG has maintained an approximately $30 \%$ mortality advantage compared to $\mathrm{PCl}$. The other outcomes used showed the same lack of change over the years. These findings held true among insulinrequiring and non-insulin-requiring diabetics. However, among non-diabetics included in the 14 studies, there was no difference in mortality outcome between $\mathrm{PCl}$ and CABG.

Conclusions: The difference in outcome between PCI and $C A B G$ in diabetics has not narrowed from the beginning - with balloon angioplasty to current $\mathrm{PCl}-$ with the second generation of drug eluting stents. In contrast to the non-diabetics, there is a persistent $30 \%$ benefit in all cause mortality favouring CABG in

\section{Strengths and limitations of this study}

All the randomised trials that include people with diabetes and compare percutaneous coronary intervention with coronary artery bypass grafting are included.

- The studies are assessed for risk of bias.

- Results are compared between people with and without diabetes.

- Over time, there may be people with more complex disease who are deemed eligible for the two interventions.

diabetics, and this should be a major factor in treatment recommendation.

\section{INTRODUCTION}

Over the past 30 years, percutaneous coronary intervention (PCI) has changed from employing plain balloon angioplasty, to the use of bare metal stents (BMSs), and recently through two generations of drug eluting stents (DESs). Each of these methods has proved better than the previous versions, mainly in preventing restenosis and further intervention rather than mortality. ${ }^{1}$

In contrast, coronary artery bypass grafting (CABG) has changed less over these years, although there may be a higher proportion of arterial grafts and off-pump surgery. When PCI and CABG are compared in randomised controlled trials (RCTs) in people with multivessel disease and stable angina or acute coronary syndromes, there is a difference in findings.

In an individual patient data meta-analysis, Hlatky et $a l^{2}$ found a non-significant 
difference in all cause mortality (HR $0.91,95 \%$ CI 0.82 to 1.02), but there was little difference in all cause mortality in those without diabetes (HR $0.98,95 \% 0.86$ to 1.12), whereas those with diabetes had a larger difference (HR $0.70,95 \%$ CI 0.56 to 0.87 ). This study was too early to include PCI with DESs. In a more recent meta-analysis of summary data, Sipahi et $a \hat{l}^{3}$ did not include studies using balloon angioplasty and found reduced mortality in patients who received CABG (risk ratio (RR) $0.73,95 \% \mathrm{CI} 0.62$ to 0.86 ). This study found no evidence that the reduced mortality differed between those with and those without diabetes.

There have been two systematic reviews concentrating on people with diabetes. Verma et $a l^{t}$ found that all cause mortality was lower in patients randomised to CABG compared to those randomised to PCI (RR 0.67, 95\% CI 0.52 to 0.86 ). This study also looked at patients without diabetes and found no evidence of a difference in mortality between CABG and PCI (RR 1.03, 95\% CI 0.77 to 1.37 ). The second review was a network meta-analysis. ${ }^{5}$ While the findings were similar to what had gone before, there was a suggestion, through indirect comparisons, that the cobalt-chromium everolimus-eluting stents may have slightly closed the gap between PCI and CABG (RR 1.11, $95 \%$ CI 0.67 to 1.84 ).

In this study, we look at how the gap in mortality between PCI and CABG in diabetics has changed over the past 30 years since the advent of PCI with balloon angioplasty to current PCI with second generation DESs. In particular, we contrast the mortality results with those found in the non-diabetics captured in our review. We also explore any differences between diabetics treated with insulin and those treated without insulin. We do this using meta-regression $^{6}$ and cumulative meta-analysis. ${ }^{78}$

\section{METHODS}

\section{Search strategy}

Databases were searched using words that might identify CABG and PCI. Articles had to mention diabetes, and RCTs were selected using the highly sensitive Cochrane Collaboration strategy. Databases MEDLINE, EMBASE and the Cochrane Central register of controlled trials were searched using Ovid. An example search for MEDLINE is:

\section{PCI.mp.}

2. Angioplasty/or angioplasty, balloon, coronary/or angioplasty.mp.

3. CABG.mp. or coronary artery bypass/

4. Diabetes mellitus/or diabetes.mp.

5. 1 or 2

6. 3 and 4 and 5 .

The WHO portal for randomised trials was searched to see if there were any ongoing studies. There were no date or language restrictions. The search was carried out in December 2014 and updated in March 2015. The title and abstracts of the selected studies were read for potentially useful studies. For these studies the whole article was downloaded and read. Both authors agreed on which studies should be included. Systematic reviews and meta-analyses were read to look for other potential studies, as were the references of included studies.

Studies were included if they were on people with stable angina or acute coronary syndromes. They had to have either multivessel or left main coronary artery disease and be restricted to people with treated diabetes or report separately on people with diabetes.

\section{Outcomes}

Data were extracted on four outcomes: all cause mortality, cardiovascular mortality, MACCE (Major Adverse Cardiac or Cerebrovascular Event) and composite of death, stroke and myocardial infarction. If available, these data were collected at $1,2-4,5$ years and longer than 5 years. The outcome used in the analysis was the longest follow-up in the study. Outcomes were extracted by one author and checked by the other. Both authors agreed on the data before any analyses were carried out. Outcomes were extracted for mortality in people with treated diabetes and people without diabetes, and within the diabetic group, people treated with and without insulin.

\section{Risk of bias}

The risk of bias was assessed using the Cochrane risk of bias tool. ${ }^{9}$ This scores each study as either low, high or unclear risk of bias on six domains: sequence generation; allocation concealment; blinding; withdrawals; selective outcome reporting; and other risk of bias.

\section{Analysis}

All analysis was conducted using Stata V.13. All outcomes were used in a separate random effects meta-regression analysis. ${ }^{10}$ The RR was used as the measure of difference in outcome between those assigned to PCI and those assigned to CABG. Meta-regression is an extension to standard meta-analysis that investigates the extent to which statistical heterogeneity between the results of multiple studies can be related to one or more characteristics of the studies. ${ }^{6}$ Both year of publication and year of starting recruitment were used as covariates. Year seemed a good proxy measure with which to capture changes in technology and changes in the normal standard of care. The difference between insulin treated and non-insulin treated diabetics was tested with a meta-regression using insulin treatment status as a covariate.

The data were also subjected to a cumulative meta-analysis. In this, the studies are entered one by one in order of year of publication with a meta-analysis carried out each time a new study is added. ${ }^{7}{ }^{8}$ Small sample bias (including publication bias) was assessed by use of a funnel plot. The change in death rates with time in both groups was modelled by Poisson regression of the number of deaths, using the size of the group as an offset. 
Table 1 Characteristics of included studies

\begin{tabular}{|c|c|c|c|c|c|}
\hline Study & $\begin{array}{l}\text { Year of first } \\
\text { publication }\end{array}$ & Participants & Treatments & Outcomes* & Notes \\
\hline RITA-I & 1993 & $\begin{array}{l}\text { Coronary artery disease } \\
\text { Eligible for either treatment } \\
\text { No previous } \\
\text { revascularisation }\end{array}$ & $\begin{array}{l}\text { Balloon angioplasty ( } 510, \\
29 \text { with diabetes) } \\
\text { CABG (501, } 33 \text { with } \\
\text { diabetes) }\end{array}$ & $\begin{array}{l}\text { Primary: Composite } † \\
\text { Secondary: all cause death } \\
1,5 \text { years }\end{array}$ & $\begin{array}{l}\text { Only } 55 \% \text { had multivessel disease } \\
\text { Composite outcome did not include } \\
\text { stroke } \\
\text { Multicentre }\end{array}$ \\
\hline EAST & 1994 & $\begin{array}{l}\text { Multi-vessel disease } \\
\text { No left main disease } \\
\text { Eligible for either treatment }\end{array}$ & $\begin{array}{l}\text { Balloon angioplasty (198, } \\
49 \text { with diabetes) } \\
\text { CABG (194, } 41 \text { with } \\
\text { diabetes) }\end{array}$ & $\begin{array}{l}\text { Primary: all cause death } \\
3,8 \text { years }\end{array}$ & Single centre \\
\hline CABRI & 1995 & $\begin{array}{l}\text { Multivessel disease } \\
\text { No left main disease } \\
\text { Eligible for either treatment } \\
\text { No previous } \\
\text { revascularisation }\end{array}$ & $\begin{array}{l}\text { Balloon angioplasty plus } \\
\text { BMS ( } 541,64 \text { with } \\
\text { diabetes) } \\
\text { CABG (513, } 60 \text { with } \\
\text { diabetes) }\end{array}$ & $\begin{array}{l}\text { Primary: all cause death } \\
4 \text { years }\end{array}$ & Multicentre \\
\hline BARI & 1996 & $\begin{array}{l}\text { Multivessel disease } \\
\text { Eligible for either treatment }\end{array}$ & $\begin{array}{l}\text { Balloon angioplasty ( } 915 \text {, } \\
174 \text { with diabetes, } 76 \text { on } \\
\text { insulin) } \\
\text { CABG ( } 914,183 \text { with } \\
\text { diabetes, } 82 \text { on insulin) }\end{array}$ & $\begin{array}{l}\text { Primary: all cause death } \\
\text { Secondary: composite, } \\
\text { cardiovascular death } \\
1,3,5,10 \text { years }\end{array}$ & Multicentre \\
\hline AWESOME & 2001 & $\begin{array}{l}\text { Multivessel disease } \\
\text { Eligible for either treatment } \\
\text { High-risk patients }\end{array}$ & $\begin{array}{l}\text { Balloon angioplasty/BMS } \\
\text { (222, } 65 \text { with diabetes) } \\
\text { CABG (232, } 79 \text { with } \\
\text { diabetes) }\end{array}$ & $\begin{array}{l}\text { Primary: all cause death } \\
1,3 \text { years }\end{array}$ & $\begin{array}{l}\text { Use of stents changed from } 26 \% \text { to } \\
88 \% \text { during the } 5 \text { years of recruitment } \\
\text { Multicentre }\end{array}$ \\
\hline ERACI-II & 2001 & $\begin{array}{l}\text { Multivessel disease } \\
\text { Eligible for either treatment } \\
\text { High risk patients }\end{array}$ & $\begin{array}{l}\text { BMS }(225,39 \text { with } \\
\text { diabetes) } \\
\text { CABG }(225,39 \text { with } \\
\text { diabetes) }\end{array}$ & $\begin{array}{l}\text { Primary: MACCE } \\
\text { Secondary: all cause death } \\
1,5 \text { years }\end{array}$ & $\begin{array}{l}\text { Only reported mortality for people with } \\
\text { diabetes } \\
\text { Multicentre }\end{array}$ \\
\hline ARTS-I & 2001 & $\begin{array}{l}\text { Multivessel disease } \\
\text { Eligible for either treatment } \\
\text { No previous } \\
\text { revascularisation }\end{array}$ & $\begin{array}{l}\text { BMS ( } 601,112 \text { with } \\
\text { diabetes, } 23 \text { on insulin) } \\
\text { CABG ( } 604,96 \text { with } \\
\text { diabetes, } 16 \text { on insulin) }\end{array}$ & $\begin{array}{l}\text { Primary: MACCE } \\
\text { Secondary: all cause death, } \\
\text { composite } \\
1,3,5 \text { years }\end{array}$ & Multicentre \\
\hline sos & 2002 & $\begin{array}{l}\text { Multivessel disease } \\
\text { Eligible for either treatment } \\
\text { No previous } \\
\text { revascularisation }\end{array}$ & $\begin{array}{l}\text { BMS ( } 488,68 \text { with } \\
\text { diabetes) } \\
\text { CABG ( } 500,74 \text { with } \\
\text { diabetes) }\end{array}$ & $\begin{array}{l}\text { Primary: Revascularisation } \\
\text { Secondary: all cause death, } \\
\text { composite } \\
1,6 \text { years }\end{array}$ & Multicentre \\
\hline MASS-II & 2004 & $\begin{array}{l}\text { Stable multivessel disease } \\
\text { Eligible for either treatment }\end{array}$ & $\begin{array}{l}\text { BMS }(205,56 \text { with } \\
\text { diabetes) } \\
\text { CABG (203, } 59 \text { with } \\
\text { diabetes) }\end{array}$ & $\begin{array}{l}\text { Primary: MACCE } \\
\text { Secondary: all cause death, } \\
\text { cardiovascular death } \\
1,5 \text { years }\end{array}$ & $\begin{array}{l}\text { Diabetes either treated or high blood } \\
\text { glucose on } 2 \text { occasions } \\
\text { Single centre. }\end{array}$ \\
\hline
\end{tabular}

Continued 


\begin{tabular}{|c|c|c|c|c|c|}
\hline Study & $\begin{array}{l}\text { Year of first } \\
\text { publication }\end{array}$ & Participants & Treatments & Outcomes* $^{*}$ & Notes \\
\hline CARDia & 2010 & $\begin{array}{l}\text { Multivessel disease or } \\
\text { complex single vessel } \\
\text { disease } \\
\text { Eligible for either treatment } \\
\text { Treated diabetes }\end{array}$ & $\begin{array}{l}\mathrm{PCI}(256, \text { all with diabetes, } \\
92 \text { on insulin) } \\
\text { CABG (254, all with } \\
\text { diabetes, } 97 \text { on insulin) }\end{array}$ & $\begin{array}{l}\text { Primary: composite } \\
\text { Secondary: all cause death, } \\
\text { MACCE } \\
1,5 \text { years }\end{array}$ & $\begin{array}{l}\text { Started with BMS but DES used when } \\
\text { they became available } \\
\text { Multicentre }\end{array}$ \\
\hline SYNTAX & 2010 & $\begin{array}{l}\text { Multivessel disease or left } \\
\text { main artery disease } \\
\text { Eligible for either treatment }\end{array}$ & $\begin{array}{l}\text { DES }(903,231 \text { with } \\
\text { diabetes, } 88 \text { on insulin) } \\
\text { CABG ( } 897,221 \text { with } \\
\text { diabetes, } 87 \text { on insulin) }\end{array}$ & $\begin{array}{l}\text { Primary: MACCE } \\
\text { Secondary: All cause death, } \\
\text { cardiovascular death, composite } \\
3,5 \text { years }\end{array}$ & $\begin{array}{l}\text { Randomisation stratified by diabetes } \\
\text { status } \\
\text { Multicentre }\end{array}$ \\
\hline PRECOMBAT & 2011 & Left main artery disease & $\begin{array}{l}\text { DES ( } 300,102 \text { with } \\
\text { diabetes, } 10 \text { on insulin) } \\
\text { CABG ( } 300,90 \text { with } \\
\text { diabetes, } 9 \text { on insulin) }\end{array}$ & $\begin{array}{l}\text { Primary: MACCE } \\
2,5 \text { years }\end{array}$ & $\begin{array}{l}\text { Individual components of MACCE not } \\
\text { reported for the subgroup with diabetes } \\
\text { Multicentre }\end{array}$ \\
\hline FREEDOM & 2012 & $\begin{array}{l}\text { Multivessel disease } \\
\text { Eligible for either treatment } \\
\text { Treated diabetes }\end{array}$ & $\begin{array}{l}\text { DES (953, all with } \\
\text { diabetes, } 325 \text { on insulin) } \\
\text { CABG ( } 947, \text { all with } \\
\text { diabetes, } 277 \text { on insulin) }\end{array}$ & $\begin{array}{l}\text { Primary: composite } \\
\text { Secondary: all cause death, } \\
\text { cardiovascular death, MACCE. } \\
1,2,3,5 \text { years }\end{array}$ & Multicentre \\
\hline VA-CARDS & 2013 & $\begin{array}{l}\text { Multi-vessel disease or left } \\
\text { main artery disease } \\
\text { Eligible for either treatment } \\
\text { Treated diabetes }\end{array}$ & $\begin{array}{l}\text { DES }(104, \text { all with } \\
\text { diabetes) } \\
\text { CABG }(103 \text {, all with } \\
\text { diabetes. }\end{array}$ & $\begin{array}{l}\text { Primary: composite } \\
\text { Secondary: all cause death, } \\
\text { cardiovascular death } \\
1,2 \text { years }\end{array}$ & $\begin{array}{l}\text { Composite outcome did not include } \\
\text { stroke } \\
\text { Multicentre }\end{array}$ \\
\hline BEST & 2015 & $\begin{array}{l}\text { Multi-vessel disease } \\
\text { No left main disease } \\
\text { Eligible for either treatment }\end{array}$ & $\begin{array}{l}\text { DES }(438,177 \text { with } \\
\text { diabetes) } \\
\text { CABG }(447,186 \text { with } \\
\text { diabetes) }\end{array}$ & $\begin{array}{l}\text { Primary: composite } \\
\text { Secondary: all cause death }\end{array}$ & $\begin{array}{l}\text { Used second generation } \\
\text { (everolimus-eluting) stents }\end{array}$ \\
\hline
\end{tabular}


Table 2 Risk of bias for the included studies

\begin{tabular}{|c|c|c|c|c|c|c|}
\hline \multirow[b]{2}{*}{ Study } & \multicolumn{6}{|c|}{ Bias domain } \\
\hline & $\begin{array}{l}\text { Sequence } \\
\text { generation }\end{array}$ & $\begin{array}{l}\text { Allocation } \\
\text { concealment }\end{array}$ & Blinding & Withdrawals & $\begin{array}{l}\text { Selective outcome } \\
\text { reporting }\end{array}$ & Other \\
\hline RITA-I & Low & Low & Low & Low & Low & Low \\
\hline EAST & Unclear & Unclear & Low & Low & Low & Unclear \\
\hline CABRI & Unclear & Low & Low & Low & Low & Low \\
\hline BARI & Low & Low & Low & Low & Low & Low \\
\hline AWESOME & Low & Unclear & Low & Low & Low & Low \\
\hline ERACI-II & Low & Unclear & Low & Low & Low & Low \\
\hline ARTS-I & Unclear & Unclear & Low & Low & Low & Low \\
\hline sos & Unclear & Unclear & Low & Low & Low & Low \\
\hline MASS-II & Unclear & Unclear & Low & Low & Low & Unclear \\
\hline CARDia & Low & Low & Low & Low & Low & Low \\
\hline SYNTAX & Low & Low & Low & Low & Low & Low \\
\hline PRECOMBAT & Low & Low & Low & Low & Low & Low \\
\hline FREEDOM & Low & Low & Low & Low & Low & Low \\
\hline VA-CARDS & Unclear & Unclear & Low & Low & Low & Low \\
\hline BEST & Low & Low & Low & Low & Low & Low \\
\hline
\end{tabular}

\section{RESULTS}

The first phase of the search turned up 896 articles, of which 106 were selected for review of the full articles after reading the titles and abstracts. Of these, 37 articles were selected for inclusion, and data were abstracted from 29. These reported on 14 studies, RITA-I, ${ }^{11}$ EAST, ${ }^{12}$ CABRI,${ }^{13}$ BARI, ${ }^{14-16}$ ARTS-I, ${ }^{17-20}$ AWESOME, ${ }^{21}$ ERACI-II, ${ }^{22}$ SOS $^{23}$ MASS-II ${ }^{24}{ }^{25}$ CARDia, ${ }^{26}{ }^{27}$ SYNTAX, ${ }^{28-31}$ PRECOMBAT, $^{32}{ }^{33}$ FREEDOM $^{34-36}$ and VA-CARDS. ${ }^{37}$ A very recent article with the results of the BEST study is also included. ${ }^{38}$ Some details of these studies are presented in table 1. The only outcome reported for participants with diabetes in the PRECOMBAT study was MACCE. ${ }^{32}$ These 14 studies included 4868 people with diabetes, 2449 of whom were randomised to PCI and 2419 to CABG.
All studies were at low to moderate risk of bias, with none of the domains being scored as high risk of bias for any study (table 2). The reporting of sequence generation and allocation concealment was poor in 6 and 7 of the 14 studies, respectively, and these were scored as unknown risk of bias. As the primary outcome was all cause mortality, this may not be a serious risk of bias. The risk of bias from blinding and withdrawals was low. In studies where people with diabetes were only a subgroup, sometimes only mortality was reported, but this is unlikely to be selectively based on statistical significance. Two studies were single centre (EAST, MASS-II) and those studies have been reported to give larger differences than multicentre trials. ${ }^{39}$

The meta-regression shows no relationship between the year of publication and the difference in all cause
Figure 1 Relationship of difference in all cause mortality between $\mathrm{PCl}$ and $\mathrm{CABG}$ with year of first publication. CABG, coronary artery bypass graft; $\mathrm{PCl}$, percutaneous coronary intervention; $R R$, risk ratio.

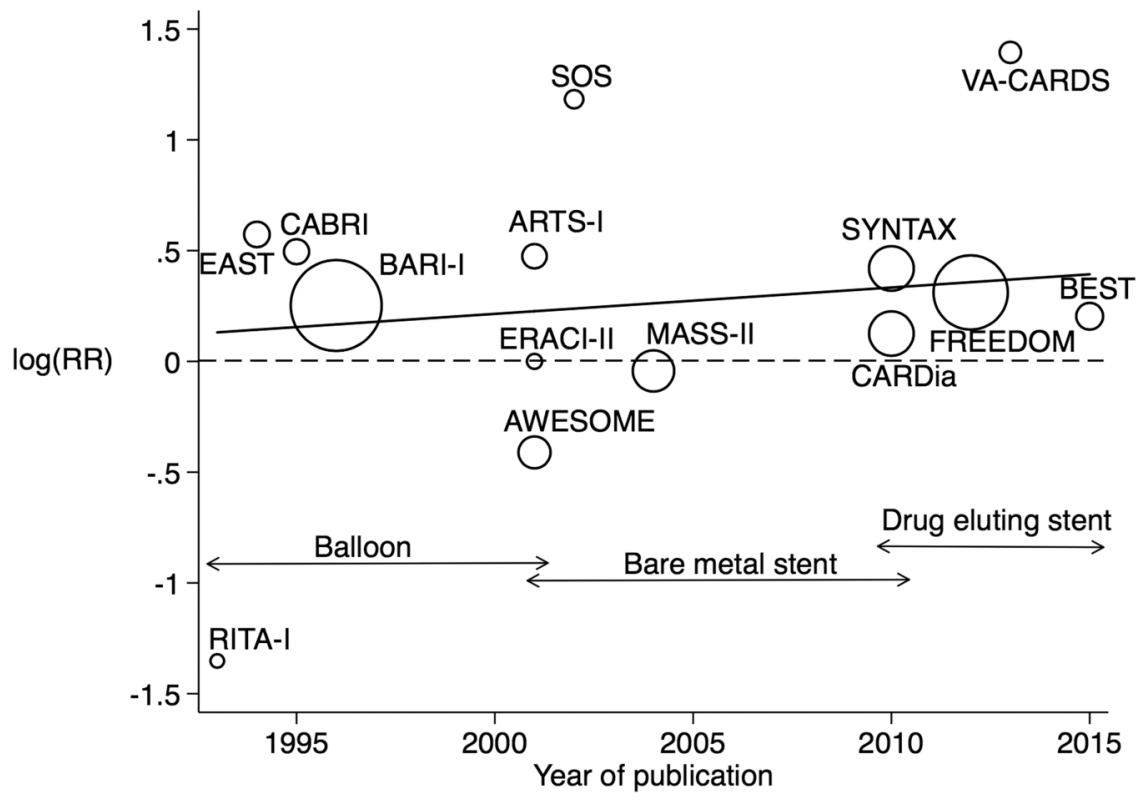


Figure 2 Cumulative meta-analysis by year of publication of the difference in all cause mortality between $\mathrm{PCl}$ and CABG in people with $(A)$ and without (B) diabetes. CABG, coronary artery bypass graft; $\mathrm{PCl}$, percutaneous coronary intervention; $\mathrm{RR}$, risk ratio.

A Diabetic

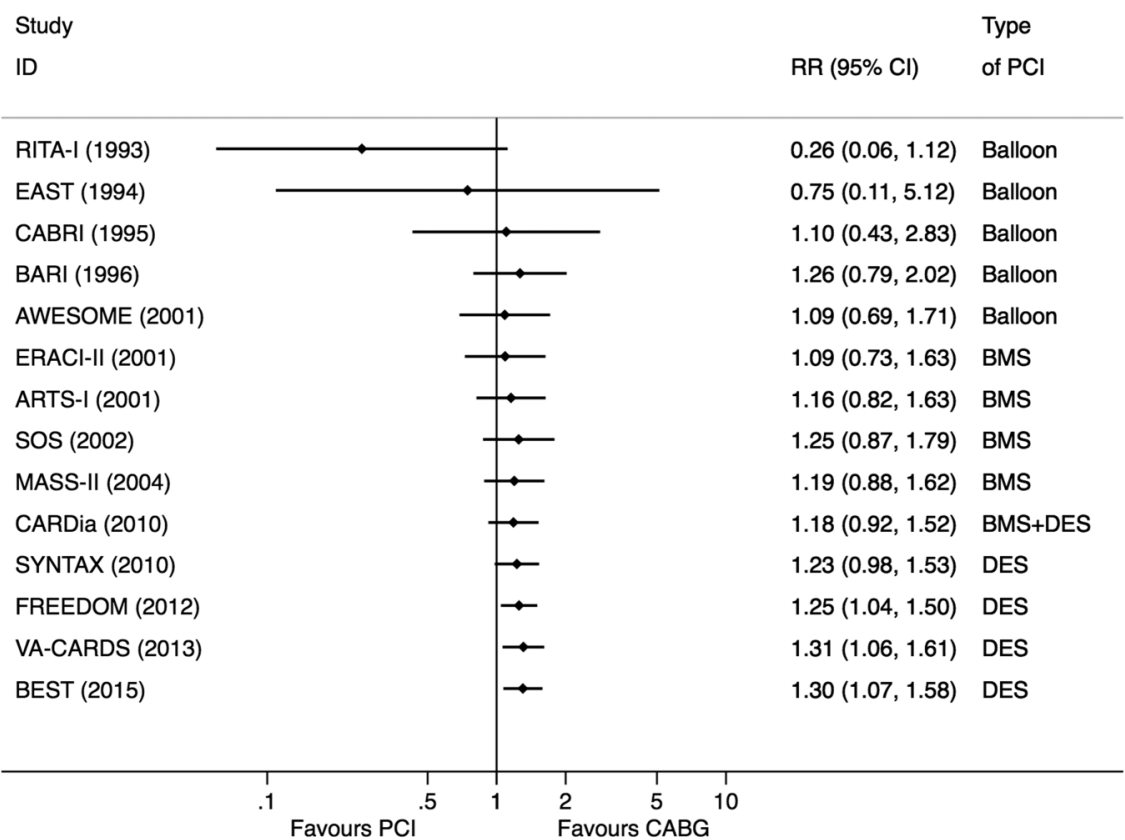

B Non-Diabetic

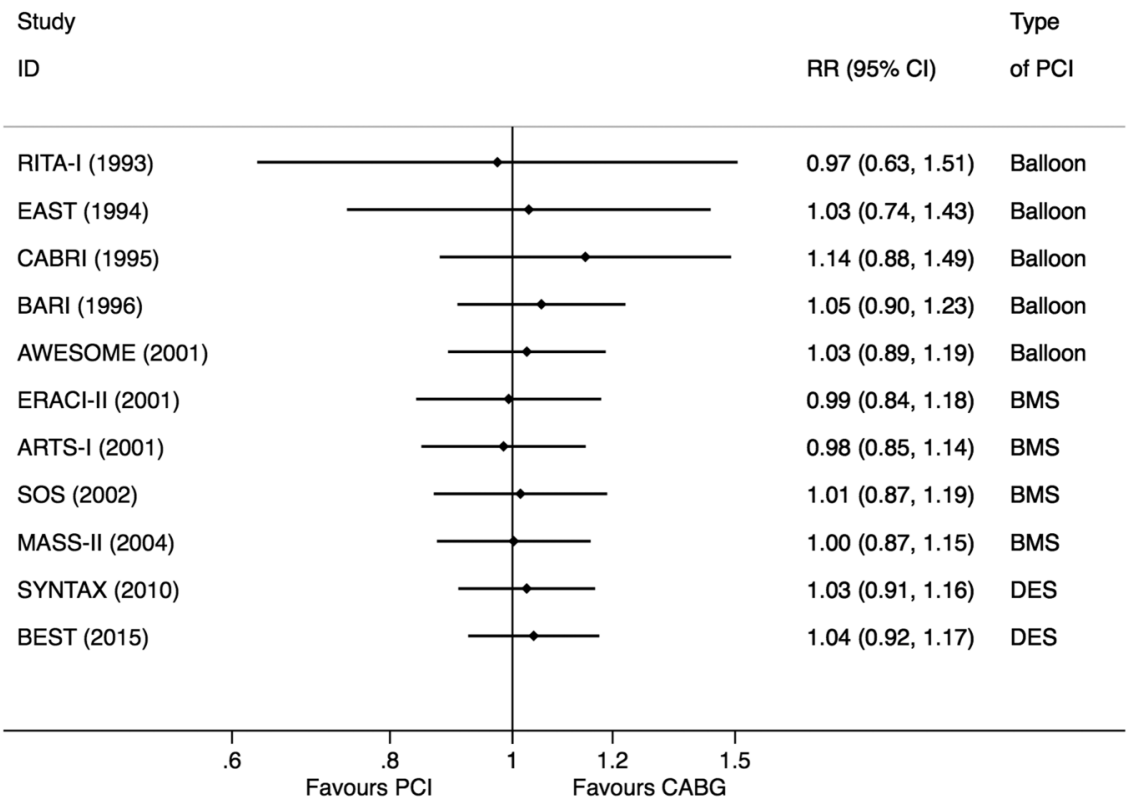

mortality between PCI and CABG (exponentiated coefficient $1.012,95 \%$ CI 0.974 to 1.051 ). This means the RR for the difference in all cause mortality has increased by $1.2 \%$ per year over the time of the study. Figure 1 displays the results graphically.

As RITA-I included many people with single vessel disease, the analysis was repeated without this study and the coefficient was closer to 1 (exponentiated coefficient $1.005,95 \%$ CI 0.972 to 1.039 ). Using year of first recruitment resulted in very similar results (exponentiated coefficient $1.012,95 \%$ CI 0.975 to 1.051 ).
Figure 2 shows the results of the cumulative meta-analysis in diabetics (figure 2A) and non-diabetics (figure 2B). There is no evidence of a change in the result with the different stents. The difference in diabetics only becomes statistically significant in 2012, after the publication of the FREEDOM trial, while in nondiabetics, the difference is always centred on 1 (RR 1.04, $95 \%$ CI 0.92 to 1.17 ).

These results mean that the best evidence for a difference in mortality between PCI and CABG in diabetics will come from a simple random effects meta-analysis of 

difference in all cause mortality between $\mathrm{PCl}$ and $\mathrm{CABG}$ in people with diabetes. CABG, coronary artery bypass graft; $\mathrm{PCl}$, percutaneous coronary intervention; $R R$, risk ratio.
Figure 3 Forest plot of the

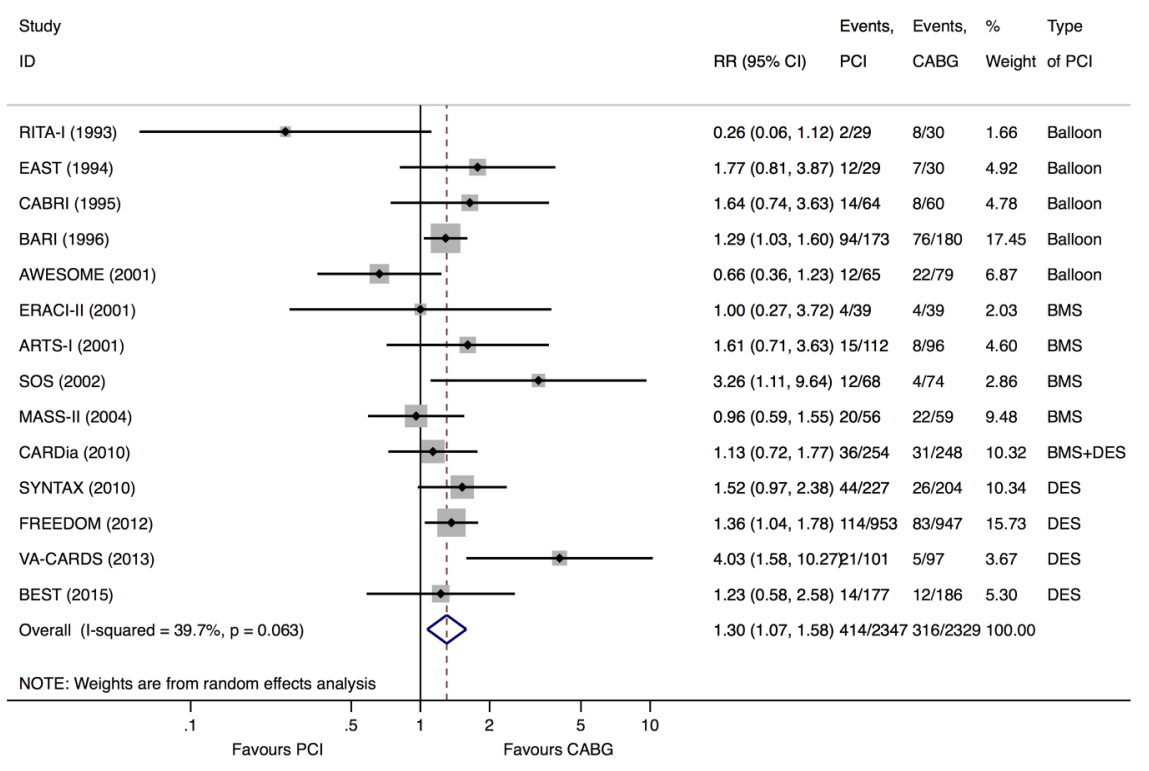

13 of these studies (PRECOMBAT did not report all cause mortality for diabetics). This results in a RR of $1.30,95 \%$ CI 1.07 to 1.58 , in favour of CABG. The forest plot for this analysis is figure 3. There was no excess heterogeneity in this meta-analysis $\left(\mathrm{I}^{2}=39.7 \%\right)$.

There is no evidence of small sample biases, such as publication bias, that would show up as asymmetry in the funnel plot in this group of studies (figure 4).

The rate of death for both PCI and CABG changed over the period in which the studies were carried out. The rate reduced by $6 \%$ per year (incidence rate ratio $($ IRR $)=0.9495 \%$ CI 0.93 to 0.95 ) in the PCI groups and $7 \%$ per year (IRR $0.9395 \%$ CI 0.92 to 0.94 ) in the CABG groups.

When the meta-regression analysis was repeated for the other outcomes, there was again no evidence of a change over time. The exponentiated coefficients were $0.966,95 \%$ CI 0.907 to 1.028 for cardiovascular death,

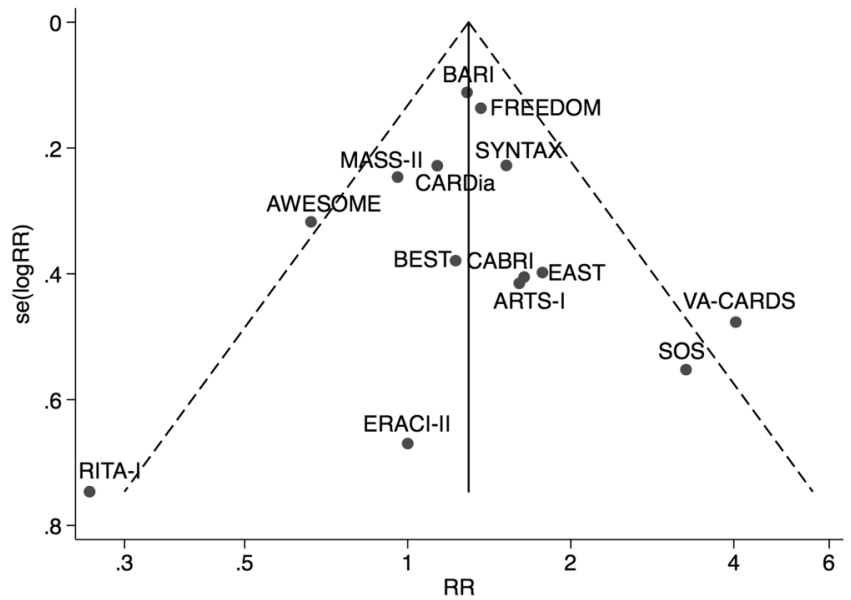

Figure 4 Funnel plot for the meta-analysis of all cause mortality. $\mathrm{RR}$, risk ratio.
$1.007,95 \%$ CI 0.985 to 1.029 for the composite end point and $0.964,95 \%$ CI 0.903 to 1.028 for MACCE.

Insulin use status and outcome data were available for 3427 patients from five studies. There was no evidence that there was a difference in outcome in those people with diabetes who were treated with and without insulin. The exponentiated coefficients in the meta-regressions were $0.85,95 \%$ CI 0.43 to 1.68 for all cause mortality, $0.98,95 \%$ CI 0.53 to 1.80 for MACCE, $1.31,95 \%$ CI 0.58 to 2.95 for the composite outcome and $1.09,95 \%$ CI 0.43 to 2.77 for cardiovascular death.

\section{DISCUSSION}

This study shows that the (relative) difference between outcomes, especially all cause mortality, between PCI and CABG has not changed over the past 30 years in diabetics with multivessel or left main vessel disease with the slope of the meta-regression line being 1.012, 95\% CI 0.974 to 1.051 . This is despite the improvements in PCI and the changes in usual care. Given this lack of change, it would appear to be valid to combine all studies into a meta-analysis. This gives a best estimate of the difference in all cause mortality between PCI and CABG in people with diabetes as a $30 \%$ increase, $95 \%$ CI $7 \%$ to $58 \%$. In the subset of studies where data are available on the use of insulin, the status of insulin requirement does not alter this finding. In contrast, the difference in non-diabetics is always small and nonstatistically significant. Including all the evidence gives a final RR of 1.04 (95\% CI 0.92 to 1.17).

While there have been well recognised advances with PCI equipment and techniques, there is less 'publicity' on advances with CABG. In those randomised to CABG, there has been a decrease in death rate over the years. This decrease was similar to that seen in the PCI arm. Many factors might explain the improved outcomes 
after $\mathrm{CABG}$, such as the increased use of arterial grafts, although even the earliest included trial used arterial grafts on $74 \%$ of people randomised to surgery. ${ }^{11}$ On the other hand, this decrease may not be because of the increased use of off-pump operations. ${ }^{40}$

As these randomised studies spanned over three decades, they had slightly different inclusion and exclusion criteria, with, for example, some studies including and some excluding patients with left main vessel disease. But in each trial, the characteristics of patients undergoing CABG or PCI would be similar. The same applies to the medicines used on discharge, which will also have changed over the years and have an impact on outcomes.

Angiographic characteristics have a very strong influence on the outcome after PCI and to a lesser extent after CABG. Advances in PCI technology (from balloon angioplasties to stenting and from bare-metal stents to DESs) over the decades have rendered a lot of complex coronary lesions amenable to both therapies, possibly also rerouting many simpler lesions to PCI. Unfortunately, these characteristics have not been sufficiently quantified until recently, with the angiographic SYNTAX score.

Nevertheless, in controlled clinical trials over these decades, where randomisation of patients involved clinical judgement of equipoise between PCI and CABG, there has consistently been a survival advantage in diabetic patients from CABG with an approximate 30\% increased long-term survival, as shown in the current review. Despite the fact that only a proportion of the studies reported on the status of insulin requirement in the diabetics, the finding stands for insulin-requiring and non-insulin-requiring diabetics. For this analysis, we updated our prior review ${ }^{41}$ of insulin versus non-insulin treatment by including data from the FREEDOM trial. ${ }^{36}$

The advantage of having more coronary conduits with CABG may be especially relevant in diabetics because of their higher risks of having coronary events despite receiving medical therapies commonly used at the time of the study. Compared to non-diabetics, diabetics have higher risks of $\mathrm{PCI} /$ stent-related complications such as subacute thrombosis and restenosis, as well as higher rates of restenosis even with DESs. ${ }^{42}$

In a recent network meta-analysis comparing PCI with CABG, excess repeat revascularisation with PCI was found that progressively declined from balloon angioplasty $(341 \%$ increase) to BMSs $(218 \%$ increase $)$ to paclitaxel-eluting stents $(81 \%$ increase $)$ and to sirolimus-eluting stents (47\% increase). ${ }^{5}$ However, for PCI with the second generation cobalt-chromium everolimus-eluting stent, where only indirect comparison was available, the excess repeat revascularisation was not statistically significant ( $R R=1.31,95 \%$ CI 0.74 to 2.29) although the point estimate still favoured CABG.

In the BEST trial of 980 patients including 263 diabetics (which has been included in the current analysis), using second generation everolimus eluting stents, ${ }^{38}$
CABG still outperformed PCI, particularly in diabetics ( $p$ value for interaction 0.06 for mortality outcome).

In those studies that were not exclusively performed in diabetics, the randomisation was only stratified by diabetes status for the SYNTAX trial, meaning that it was possible that there was some imbalance at baseline in the diabetic groups. An individual patient level data meta-analysis may be able to adjust for differences in the characteristics of the participants.

The CIs were quite wide around most estimates, so it is possible that some of the differences, while not statistically significant, were clinically important.

It is most likely that the evolution of PCI over the decades has already impacted physicians' judgement as to whether the diabetic patient is equally suited for PCI and $\mathrm{CABG}$, and the equipoise of the two therapies has been shifting towards angiographically more complex lesions over the years.

On current evidence, CABG must be the preferred option over PCI in patients with diabetes and multivessel coronary artery disease when otherwise judged to be in clinical equipoise. CABG reduces mortality and reintervention compared to PCI, unlike the situation in nondiabetics. Whether the newer generation of DES may bridge the gap in the future remains a hypothesis to be proven.

\section{Author affiliations}

${ }^{1}$ Department of Preventive and Social Medicine, Dunedin School of Medicine, University of Otago, Dunedin, New Zealand

${ }^{2}$ Department of Medicine, Dunedin School of Medicine, University of Otago, Dunedin, New Zealand

${ }^{3}$ Department of Medicine and Therapeutics, Chinese University of Hong Kong Shatin, New Territories, Hong Kong

Contributors PH refined the idea, searched and screened papers, extracted data and carried out the analysis, wrote the first draft of the paper, gave final approval of the paper and is the guarantor of the paper; CKW came up with the idea, checked searches and data extraction, critically revised the paper and gave final approval of the paper.

Funding This work was supported by the Health Research Council of New Zealand grant number 12/256.

Competing interests None declared.

Provenance and peer review Not commissioned; externally peer reviewed.

Data sharing statement No additional data are available.

Open Access This is an Open Access article distributed in accordance with the Creative Commons Attribution Non Commercial (CC BY-NC 4.0) license, which permits others to distribute, remix, adapt, build upon this work noncommercially, and license their derivative works on different terms, provided the original work is properly cited and the use is non-commercial. See: http:// creativecommons.org/licenses/by-nc/4.0/

\section{REFERENCES}

1. Greenhalgh J, Hockenhull J, Rao N, et al. Drug-eluting stents versus bare metal stents for angina or acute coronary syndromes. Cochrane Database Syst Rev 2010;(5):CD004587.

2. Hlatky MA, Boothroyd DB, Bravata DM, et al. Coronary artery bypass surgery compared with percutaneous coronary interventions for multivessel disease: a collaborative analysis of individual patient data from ten randomised trials. Lancet 2009;373:1190-7.

3. Sipahi I, Akay MH, Dagdelen S, et al. Coronary artery bypass grafting vs percutaneous coronary intervention and long-term 
mortality and morbidity in multivessel disease: meta-analysis of randomized clinical trials of the arterial grafting and stenting era. JAMA Intern Med 2014;174:223-30.

4. Verma S, Farkouh ME, Yanagawa B, et al. Comparison of coronary artery bypass surgery and percutaneous coronary intervention in patients with diabetes: a meta-analysis of randomised controlled trials. Lancet Diabetes Endocrinol 2013;1:317-28.

5. Bangalore S, Toklu B, Feit F. Outcomes with coronary artery bypass graft surgery versus percutaneous coronary intervention for patients with diabetes mellitus: can newer generation drug-eluting stents bridge the gap? Circ Cardiovasc Interv 2014;7:518-25.

6. Thompson SG, Higgins JP. How should meta-regression analyses be undertaken and interpreted? Stat Med 2002;21:1559-73.

7. Lau J, Schmid CH, Chalmers TC. Cumulative meta-analysis of clinical trials builds evidence for exemplary medical care. J Clin Epidemiol 1995;48:45-57.

8. Lau J, Antman EM, Jimenez-Silva J, et al. Cumulative meta-analysis of therapeutic trials for myocardial infarction. $N$ Engl J Med 1992;327:248-54

9. Higgins JPT, Altman DG, Gotzsche PC, et al. The Cochrane Collaboration's tool for assessing risk of bias in randomised trials. BMJ 2011;343:d5928.

10. Harbord RM, Higgins JP. Meta-regression in Stata. Stata J 2008;8:493-519.

11. Henderson RA, Pocock SJ, Sharp SJ, et al. Long-term results of RITA-1 trial: clinical and cost comparisons of coronary angioplasty and coronary-artery bypass grafting. Randomised Intervention Treatment of Angina. Lancet 1998;352:1419-25.

12. King SB, Kosinski AS, Guyton RA, et al. Eight-year mortality in the Emory Angioplasty versus Surgery Trial (EAST). J Am Coll Cardiol 2000;35:1116-21.

13. Kurbaan AS, Bowker TJ, Ilsley CD, et al. Difference in the mortality of the CABRI diabetic and nondiabetic populations and its relation to coronary artery disease and the revascularization mode. Am J Cardiol 2001;87:947-50.

14. Frye RL, Alderman EL, Andrews K, et al. Comparison of coronary bypass surgery with angioplasty in patients with multivessel disease: the Bypass Angioplasty Revascularization Investigation (BARI) investigators. N Engl J Med 1996;335:217-25.

15. Chaitman BR, Rosen AD, Williams DO, et al. Myocardial infarction and cardiac mortality in the Bypass Angioplasty Revascularization Investigation (BARI) randomized trial. Circulation 1997;96:2162-70.

16. The BARI Investigators. The final 10-year follow-up results from the BARI randomized trial. J Am Coll Cardiol 2007;49:1600-6.

17. Abizaid A, Costa MA, Centemero M, et al. Clinical and economic impact of diabetes mellitus on percutaneous and surgical treatment of multivessel coronary disease patients: insights from the Arterial Revascularization Therapy Study (ARTS) trial. Circulation 2001;104:533-8.

18. Legrand VM, Serruys PW, Unger F, et al. Three-year outcome after coronary stenting versus bypass surgery for the treatment of multivessel disease. Circulation 2004;109:1114-20.

19. Serruys PW, Ong ATL, van Herwerden LA, et al. Five-year outcomes after coronary stenting versus bypass surgery for the treatment of multivessel disease: the final analysis of the arterial revascularization therapies study (ARTS) randomized trial. J Am Coll Cardiol 2005;46:575-81.

20. Daemen J, Kuck KH, Macaya C, et al. Multivessel coronary revascularization in patients with and without diabetes mellitus: 3-year follow-up of the ARTS-II (Arterial Revascularization Therapies Study-Part II) trial. J Am Coll Cardiol 2008;52:1957-67.

21. Sedlis SP, Morrison DA, Lorin JD, et al. Percutaneous coronary intervention versus coronary bypass graft surgery for diabetic patients with unstable angina and risk factors for adverse outcomes with bypass: outcome of diabetic patients in the AWESOME randomized trial and registry. J Am Coll Cardiol 2002;40:1555-66.

22. Rodriguez AE, Baldi J, Fernández Pereira C, et al. Five-year follow-up of the Argentine randomized trial of coronary angioplasty with stenting versus coronary bypass surgery in patients with multiple vessel disease (ERACI II). J Am Coll Cardiol 2005;46:582-8.

23. Booth J, Clayton T, Pepper J, et al. Randomized, controlled trial of coronary artery bypass surgery versus percutaneous coronary intervention in patients with multivessel coronary artery disease:
Six-year follow-up from the Stent or Surgery Trial (SoS). Circulation 2008;118:381-8.

24. Soares PR, Hueb WA, Lemos PA, et al. Coronary revascularization (surgical or percutaneous) decreases mortality after the first year in diabetic subjects but not in nondiabetic subjects with multivesse disease: an analysis from the Medicine, Angioplasty, or Surgery Study (MASS II). Circulation 2006;114(1 Suppl):1420-4.

25. Lima EG, Hueb W, Garcia RM, et al. Impact of diabetes on 10-year outcomes of patients with multivessel coronary artery disease in the Medicine, Angioplasty, or Surgery Study II (MASS II) trial. Am Heart J 2013;166:250-7.

26. Kapur A, Hall RJ, Malik IS, et al. Randomized comparison of percutaneous coronary intervention with coronary artery bypass grafting in diabetic patients: 1-year results of the CARDia (Coronary Artery Revascularization in Diabetes) trial. J Am Coll Cardiol 2010;55:432-40.

27. Baumbach A, Kesavan S, Cruddas E, et al. Outcome of coronary revascularisation in insulin treated and non insulin treated diabetic patients. Euro Heart J 2011;32:1044.

28. Banning AP, Westaby S, Morice MC, et al. Diabetic and nondiabetic patients with left main and/or 3-vessel coronary artery disease: comparison of outcomes with cardiac surgery and paclitaxel-eluting stents. J Am Coll Cardiol 2010;55:1067-75.

29. Mack MJ, Banning AP, Serruys PW, et al. Bypass versus drug-eluting stents at three years in SYNTAX patients with diabetes mellitus or metabolic syndrome. Ann Thorac Surg 2011;92: 2140-6.

30. Kappetein AP, Head SJ, Morice M, et al. Treatment of complex coronary artery disease in patients with diabetes: 5-year results comparing outcomes of bypass surgery and percutaneous coronary intervention in the syntax trial. Eur J Cardiothorac Surg 2013;43:1006-13.

31. Morice MC, Serruys PW, Kappetein AP, et al. Five-Year outcomes in patients with left main disease treated with either percutaneous coronary intervention or coronary artery bypass grafting in the synergy between percutaneous coronary intervention with taxus and cardiac surgery trial. Circulation 2014;129:2388-94.

32. Park SJ, Kim YH, Park DW, et al. Randomized trial of stents versus bypass surgery for left main coronary artery disease. $N$ Engl $\mathrm{J}$ Med 2011;364:1718-27.

33. Ahn JM, Roh JH, Kim YH, et al. Randomized trial of stents versus bypass surgery for left main coronary artery disease: five-year outcomes of the PRECOMBAT study. J Am Coll Cardiol 2015;65:2198-206. Epub 2015/03/20.

34. Farkouh ME, Domanski M, Sleeper LA, et al. Strategies for multivessel revascularization in patients with diabetes. $N$ Eng $J$ Med 2012;367:2375-84.

35. Aggarwal B, Goel SS, Sabik JF, et al. The FREEDOM trial: in appropriate patients with diabetes and multivessel coronary artery disease, CABG beats PCI. Cleve Clin J Med 2013;80:515-23.

36. Dangas GD, Farkouh ME, Sleeper LA, et al. Long-term outcome of $\mathrm{PCl}$ versus $\mathrm{CABG}$ in insulin and non-insulin-treated diabetic patients: results from the FREEDOM trial. J Am Coll Cardiol 2014;64:1189-97

37. Kamalesh M, Sharp TG, Tang XC, et al. Percutaneous coronary intervention versus coronary bypass surgery in United States veterans with diabetes. J Am Coll Cardiol 2013;61:808-16.

38. Park S-J, Ahn J-M, Kim Y-H, et al. Trial of everolimus-eluting stents or bypass surgery for coronary disease. $N$ Eng $J$ Med 2015;372:1204-12.

39. Bafeta A, Dechartres A, Trinquart L, et al. Impact of single centre status on estimates of intervention effects in trials with continuous outcomes: meta-epidemiological study. BMJ 2012;344:e813.

40. Møller $\mathrm{CH}$, Penninga L, Wetterslev J, et al. Off-pump versus on-pump coronary artery bypass grafting for ischaemic heart disease. Cochrane Database Syst Rev 2012(3):CD007224.

41. Lee BJ, Herbison P, Wong CK. Is the advantage of coronary bypass graft surgery over percutaneous coronary intervention in diabetic patients with severe multivessel disease influenced by the status of insulin requirement? J Geriatr Cardiol 2014;11:83-9.

42. Lüscher TF, Steffel J, Eberli FR, et al. Drug-eluting stent and coronary thrombosis: biological mechanisms and clinical implications. Circulation 2007;115:1051-8. 